\title{
Determination of Optimum Extraction Conditions for Lithium, Rubidium, and Cesium From Boron Industrial Waste and Analysis by FAAS
}

\author{
Ferda Özmal ${ }^{a}, *$, Yunus Erdogan ${ }^{\mathrm{b}}$, and Melike Kale ${ }^{\mathrm{a}}$ \\ ${ }^{a}$ Dumlupinar University, Science and Art Faculty, Biochemistry Department, 43100 Kütahya, Turkey \\ b Dumlupinar University, Science and Art Faculty, Chemistry Department,, 43100 Kütahya, Turkey
}

\section{INTRODUCTION}

Turkey has the largest boron reserves in the world with approximately 50\% in the Emet-Hisarc1k region. The ore is called colemanite $\left(2 \mathrm{CaO} \cdot 3 \mathrm{~B}_{2} \mathrm{O}_{3} \cdot 5 \mathrm{H}_{2} \mathrm{O}\right)$. The Emet Boron Process Management Company has one concentrator in Hisarcik and another in Emet, including two boron factories in Emet, each with a production capacity of 120,000 tonnes of $\mathrm{H}_{3} \mathrm{BO}_{3}$ per year. While the colemanite ore is being enriched in concentrators, nearly half of it becomes waste, such as hand-sorting waste, $-25 \mathrm{~mm}$ solid waste, and $-3 \mathrm{~mm}$ dam waste (1). The analysis of macro elements in these wastes and the boron minerals is performed routinely, but few studies have reported the determination of micro elements. Some studies have reported that a significant amount of lithium (Li), rubidium (Rb), and cesium (Cs) is in these wastes (2-4).

According to our research, industrial boron waste contains at least 300-600 mg/kg lithium (3). Lithium and its compounds have become of strategic importance for today and tomorrow. It is used for the production of light alloy in the manufacture of aircrafts, for the development of environmentally friendly cars, according to the ${ }^{6} \mathrm{Li}+\mathrm{n} \rightarrow{ }^{3} \mathrm{H}+{ }^{4} \mathrm{He}$ reaction for nuclear fusion, is the alternative energy fuel of the future, and for rechargable batteries of mobile devices $(5,3)$. The selling price of lithium carbonate is listed as $\$ 6.4 / \mathrm{kg}(6)$.

\footnotetext{
*Corresponding author.

E-mail:ferda.ozmal@dpu.edu.tr,

gpmelike@hotmail.com

Tel: +902742652051/3705
}

\begin{abstract}
In this study, boron waste (-25 mm solid waste) obtained during the enrichment process of colemanite mineral at Emet-Espey was analyzed and $\mathrm{Li}, \mathrm{Rb}$, and $\mathrm{Cs}$ determined by atomic absorption spectrometry. Although these valuable metals have extremely important and strategic use, they are not found in Turkey. Since they are present at fairly high amounts in boron waste, an efficient and economical extraction method has been investigated. In order to increase the extraction yield of these metals by water leaching process, boron waste was roasted with chlorinating agents $(\mathrm{NaCl}$ and $\mathrm{CaCl}_{2}$ ). The parameters used to determine the optimum extraction conditions were roasting temperature, weight ratio of the chlorinating agents to boron waste, roasting time, leaching temperature, leaching time and solid-to-liquid (S/L) ratio. The maximum extraction values achieved for $\mathrm{Li}, \mathrm{Rb}$, and $\mathrm{Cs}$ were $75.01 \%, 84.15 \%$, and $89.90 \%$, respectively, with a mass ratio of boron waste/ $\mathrm{NaCl} / \mathrm{CaCl}_{2}$ of 1:0.6:0.4 at $700{ }^{\circ} \mathrm{C}$ for $120 \mathrm{~min}$ utes, at the leaching temperature and time of $60^{\circ} \mathrm{C}$ and 45 minutes, and a $\mathrm{S} / \mathrm{L}$ ratio of 0.4 . This method can also be applied to minerals, clays, and other types of inorganic wastes containing $\mathrm{Li}, \mathrm{Rb}$, and $\mathrm{Cs}$.
\end{abstract}

Rubidium is mainly used for specialty glasses in fiber optic telecommunication systems, for night vision devices, in photoelectric cells, and in photomultiplier tubes owing to its photoemmissive properties. Rubidium use in medical sciences is also of great importance. Rubidium salts are used in epilepsy treatment and rubidium-82 in positron emission tomographic imaging as a blood-flow tracer (7). Rubidium has no minerals of its own and is found in pegmatites. A number of studies have been published on the extraction of rubidium from minerals or different kinds of wastes with the methods such as direct acid leaching, salt roasting and water leaching. (8-13). According to reports from the U.S. Geological Survey, the price of $1 \mathrm{~g}$ and $100 \mathrm{~g}$ of $99.75 \%$-grade metallic rubidium is $\$ 80.30$ and $\$ 1,472.00$, respectively (14).

Non-radioactive cesium is mostly used for petroleum exploration and as a high-density component in drilling mud for lubrication of drill bits and for maintaining pressure on the oil-bearing strata. Other uses are for television image devices, night-vision equipment, solar photovoltaic cells, photoelectric cells, and for the super-accurate atomic cesium clock. It is also used in the chemical process industry, for medical treatments, specialty glasses, and in fiber optics (15). In 2015, one company offered $1 \mathrm{~g}$ ampoules of $99.98 \%$ (metal basis) cesium for $\$ 73.40$ (16).

Cesium and rubidium have similiar physical properties and atomic radii which enables their interchangeable use in many applications. Because cesium is more electropositive than rubidium, it is especially used in areas such as photosensitive materials (16). Thus, recovering these metals from boron wastes is of great economical value.

The aim of this study was to determine these metals in boron wastes by using a chlorination process (17). Boron waste samples 
TABLE I

WDXRF Results for $-25 \mathrm{~mm}$ Solid Waste

\begin{tabular}{|c|c|c|}
\hline $\begin{array}{l}\text { Compo- } \\
\text { nents }\end{array}$ & $\%(\mathrm{~W})$ & $\begin{array}{l}\text { Detection } \\
\text { Limit (\%) }\end{array}$ \\
\hline $\mathrm{Na}_{2} \mathrm{O}$ & 0.219 & 0.0072 \\
\hline $\mathrm{MgO}$ & 6.770 & 0.0074 \\
\hline $\mathrm{Al}_{2} \mathrm{O}_{3}$ & 10.90 & 0.0068 \\
\hline $\mathrm{SiO}_{2}$ & 37.40 & 0.0092 \\
\hline $\mathrm{P}_{2} \mathrm{O}_{5}$ & 0.205 & 0.0010 \\
\hline $\mathrm{SO}_{3}$ & 0.243 & 0.0012 \\
\hline $\mathrm{Cl}$ & 0.014 & 0.0017 \\
\hline $\mathrm{F}$ & 0.661 & 0.0530 \\
\hline $\mathrm{K}_{2} \mathrm{O}$ & 3.770 & 0.0022 \\
\hline $\mathrm{CaO}$ & 6.390 & 0.0023 \\
\hline $\mathrm{TiO}_{2}$ & 0.528 & 0.0058 \\
\hline $\mathrm{Cr}_{2} \mathrm{O}_{3}$ & 0.0213 & 0.0027 \\
\hline $\mathrm{MnO}$ & 0.106 & 0.0181 \\
\hline $\mathrm{Fe}_{2} \mathrm{O}_{3}$ & 4.750 & 0.0027 \\
\hline $\mathrm{NiO}$ & 0.0188 & 0.0013 \\
\hline $\mathrm{ZnO}$ & 0.0186 & 0.0010 \\
\hline $\mathrm{GeO}_{2}$ & 0.0035 & 0.0011 \\
\hline $\mathrm{As}_{2} \mathrm{O}_{3}$ & 0.334 & 0.0052 \\
\hline SrO & 0.618 & 0.0007 \\
\hline $\mathrm{BaO}$ & 0.0632 & 0.0126 \\
\hline $\mathrm{PbO}$ & 0.0076 & 0.0019 \\
\hline $\mathrm{Y}_{2} \mathrm{O}_{3}$ & 0.0190 & 0.0007 \\
\hline $\mathrm{CuO}$ & 0.0060 & 0.0011 \\
\hline${ }^{*} \mathrm{~B}_{2} \mathrm{O}_{3}$ & 18.60 & - \\
\hline Ignition loss & 8.030 & - \\
\hline
\end{tabular}

${ }^{*} \mathrm{~B}_{2} \mathrm{O}_{3}$ analysis was performed at Emet Boric Acid Plant by volumetric method.

TABLE II

Li, Rb, and Cs Composition in $-25 \mathrm{~mm}$ Solid Waste by AAS

\begin{tabular}{cc}
\hline Components & $(\mathrm{mg} / \mathrm{kg})$ \\
\hline $\mathrm{Li}$ & $547 \pm 8$ \\
$\mathrm{Rb}$ & $679 \pm 5$ \\
$\mathrm{Cs}$ & $1416 \pm 27$ \\
\hline
\end{tabular}

*The results are the average of 3 repetitions. were roasted with chlorinating agents $\left(\mathrm{NaCl}, \mathrm{CaCl}_{2}\right)$ and leached with water. The amount of extracted $\mathrm{Li}, \mathrm{Rb}$, and $\mathrm{Cs}$ was determined by AAS from the aqueous solution. This study will be a preliminary work for researchers interested in the recovery of valuable metals from minerals, clays, or wastes.

\section{EXPERIMENTAL}

\section{Samples and Characterization}

Boron waste, obtained during the enrichment process of colemanite as $-25 \mathrm{~mm}$ solid waste, was analyzed. The sample was first dried in an oven at $110^{\circ} \mathrm{C}$ for 12 hours, then crushed and ground in a ring mill and sieved to sizes lower than $63 \mu \mathrm{m}$. The chemical analysis was performed using a Model ZSX Primus wavelength dispersive X-ray fluorescence instrument (WDXRF) (Rigaku, U.S.) and a Model ContrAA 300 atomic absorption spectrometer (AAS) (Analytikjena, Germany).

The analysis results are listed in Tables I and II. The crystalline phases of the waste were determined by X-ray diffraction (XRD)

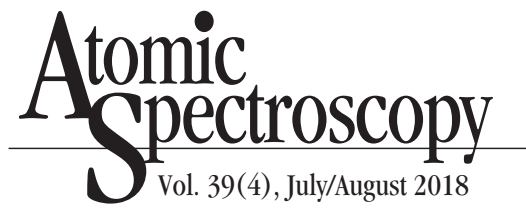

analysis (PAN Analytical Empyrean, Holland) at a speed of $2 \%$ min and $0.01^{\circ}$ steps by using $\mathrm{CuK} \alpha$ radiation between 2 and $70^{\circ}$ (see Figure 1). The main minerals are colemanite $\left(2 \mathrm{CaO} \cdot 3 \mathrm{~B}_{2} \mathrm{O}_{3} \cdot 5 \mathrm{H}_{2} \mathrm{O}\right)$, muscovite $\left(\mathrm{KAl}_{3} \mathrm{Si}_{3} \mathrm{O}_{10}(\mathrm{OH})_{2}\right)$, quartz $\left(\mathrm{SiO}_{2}\right)$, and dolomite $\left(\mathrm{CaMg}\left(\mathrm{CO}_{3}\right)_{2}\right)$. $\mathrm{Li}, \mathrm{Rb}$, and Cs concentrations of leach liquors were measured by AAS.

WDXRF analysis was carried out at the Emet Boric Acid Plant, and the AAS and XRD analyses at Dumlupinar University, Advanced Technologies in Design, Research and Development and Application Center, Turkey.

\section{Roasting and Leaching Proces}

In this study, the chlorination roasting-water leaching process was used. To extract $\mathrm{Li}, \mathrm{Rb}$, and $\mathrm{Cs}$ from boron waste, the optimum roasting temperature $(500,600$, $700,800,900^{\circ} \mathrm{C}$ ) was determined in an electrically heated furnace. The waste sample ( $5 \mathrm{~g}$ ) was roasted at the chosen temperature $\left(700^{\circ} \mathrm{C}\right)$ with $\mathrm{NaCl}$ and $\mathrm{CaCl}_{2}$ (determined by preliminary experiments) at different ratios (the ratios of chlorinating agents to boron waste were

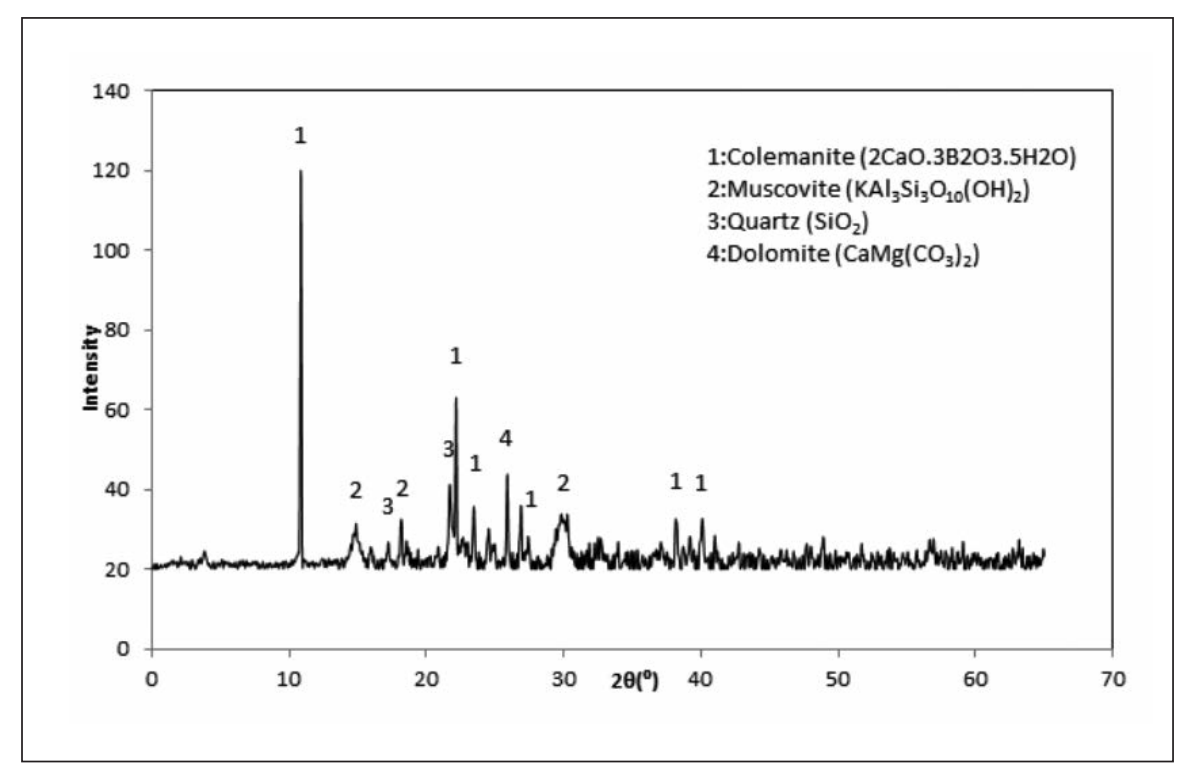

Fig. 1. XRD patterns of $-25 \mathrm{~mm}$ solid waste. 
$0.2,0.4,0.6,0.8,1.0)$, then the optimum ratios of the two chlorinating agents $\left(\mathrm{NaCl}: 0.6, \mathrm{CaCl}_{2}: 0.4\right)$ were mixed into the waste and roasted together. The roasted mixtures (boron waste and chloranating agents) were leached with 25 $\mathrm{mL}$ deionized water for one hour, then filtered with glass funnel filters with a pore size of $10-16 \mu \mathrm{m}$, and metal analysis was performed from the leach liquors of the mixtures. Roasting time (15-180 minutes) of the waste sample with the mixture of chlorinating agents at the optimum ratios and at the chosen temperature was another studied parameter. Because the roasting process is heat-dependent, the period of this process is quite important in order to avoid economical loss. Then the roasted mixtures were leached ranging from 15 to 75 minutes at $30^{\circ} \mathrm{C}, 60^{\circ} \mathrm{C}$, and $90{ }^{\circ} \mathrm{C}$, respectively. The $\mathrm{S} / \mathrm{L}$ ratio was changed from 0.1 to 1.0 in order to see the effect of this parameter on the extraction process.

\section{RESULTS AND DISCUSSION}

\section{Effect of Roasting Temperature}

The effect of roasting temperature from 500 to $900{ }^{\circ} \mathrm{C}$ on metal extraction was investigated (see Figure 2). For the three metals, the extraction efficiency increases to its maximum value at $700{ }^{\circ} \mathrm{C}$ and then decreases. The reason can be ascribed to the sample losing its plasticity property above this temperature. Therefore, further experiments were carried out at $700{ }^{\circ} \mathrm{C}$.

\section{Effect of Mass Ratio of Chlori- nating Agents to Waste Sample}

In order to increase the extraction efficiency of $\mathrm{Li}, \mathrm{Rb}$, and $\mathrm{Cs}$, a series of chlorination roasting experiments were conducted at

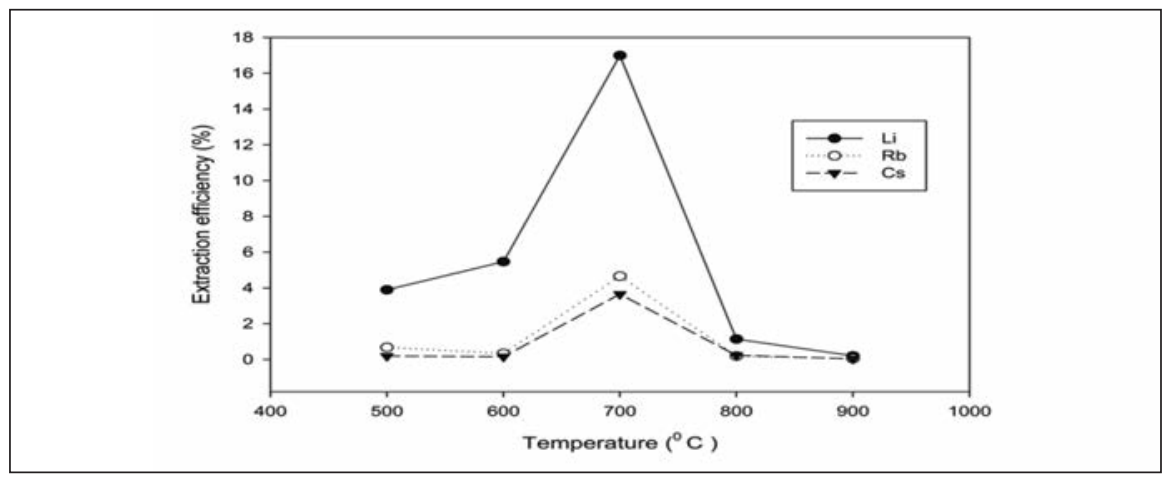

Fig. 2. Effect of roasting temperature on metal extraction (roasting time : 2 bours).

different mass ratios of $\mathrm{NaCl}$ or $\mathrm{CaCl}_{2}$ to boron waste at $700{ }^{\circ} \mathrm{C}$ for 2 hours. The results in Figures 3 and 4 , are discussed below.

As seen in Figures 3 and 4, the mass ratio of 0.6 and 0.4 is most favorable for $\mathrm{NaCl}$ and $\mathrm{CaCl}_{2}$, respectively. At the 0.6 mass ratio of $\mathrm{NaCl}$, the maximum extraction yields were $16.61 \%, 7.39 \%$, and $11.80 \%$ for $\mathrm{Li}, \mathrm{Rb}$, and $\mathrm{Cs}$, at the same order and at the 0.4 mass ratio of $\mathrm{CaCl}_{2}$ the efficiencies increase to $23.09 \%, 37.98 \%$, and $46.57 \%$, respectively. In comparison it can be seen that $\mathrm{CaCl}_{2}$ is more effective with the higher extraction efficiencies.

The reactions that occur during the extraction process were as follows $(\mathrm{R}=\mathrm{Li}, \mathrm{Rb}, \mathrm{Cs})(8)$ :

Eq. 1

$2 \mathrm{NaCl}+6 \mathrm{SiO}_{2}+\mathrm{R}_{2} \mathrm{O}+\mathrm{Al}_{2} \mathrm{O}_{3} \rightarrow$ $2 \mathrm{NaAlSi}_{3} \mathrm{O}_{8}+2 \mathrm{RCl}$

Eq. 2

$\mathrm{CaCl}_{2}+\mathrm{SiO}_{2}+\mathrm{R}_{2} \mathrm{O} \rightarrow \mathrm{CaSiO}_{3}+2 \mathrm{RCl}$

Eq. 3

$\mathrm{CaCl}_{2}+2 \mathrm{SiO}_{2}+\mathrm{Al}_{2} \mathrm{O}_{3}+\mathrm{R}_{2} \mathrm{O} \rightarrow$ $\mathrm{CaAl}_{2} \mathrm{Si}_{2} \mathrm{O}_{8}+2 \mathrm{RCl}$

The $\mathrm{SiO}_{2}$ and $\mathrm{Al}_{2} \mathrm{O}_{3}$ content in boron waste was $37.4 \%$ and $10.9 \%$, respectively, and the molar ratio of $\mathrm{SiO}_{2}$ to $\mathrm{Al}_{2} \mathrm{O}_{3}$ in the waste was 5.8. This ratio indicates that $\mathrm{CaCl}_{2}$ is more effective for decomposing boron waste.

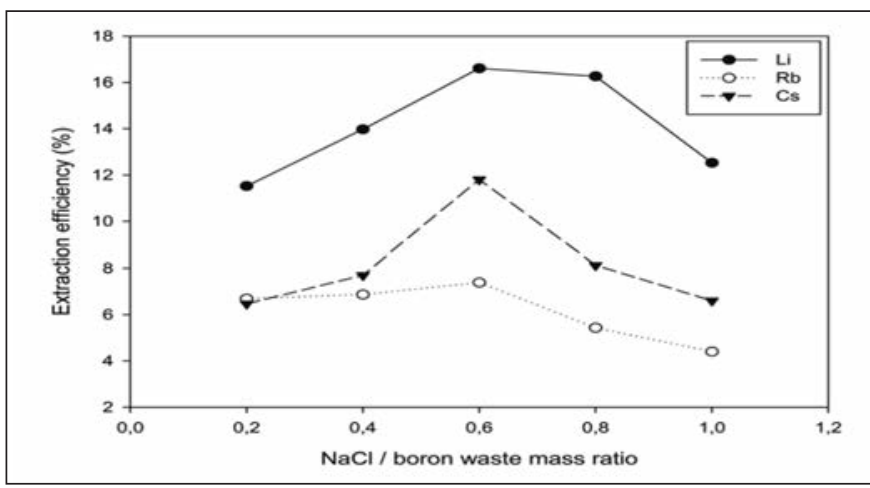

Fig. 3. Effect of mass ratio of $\mathrm{NaCl}$ to waste sample (roasting temperature: $700{ }^{\circ} \mathrm{C}$, roasting time: 2 bours).

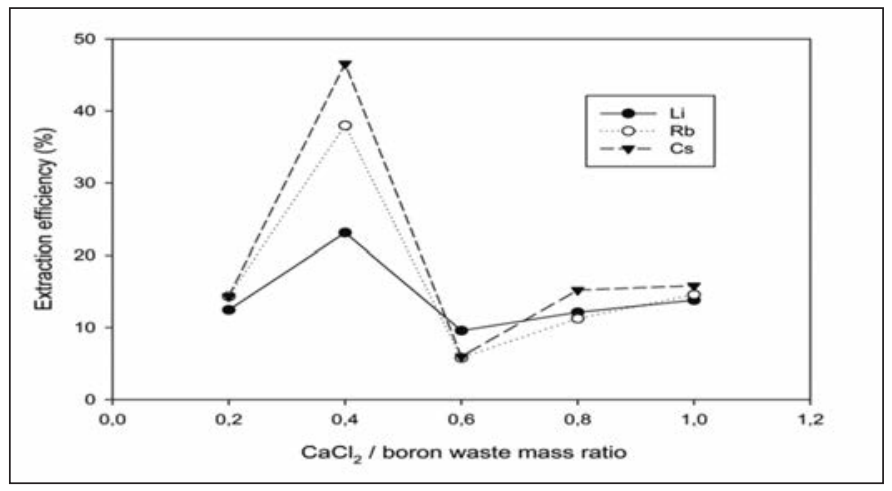

Fig. 4. Effect of mass ratio of $\mathrm{CaCl}_{2}$ to waste sample (roasting temperature: $700{ }^{\circ} \mathrm{C}$, roasting time: 2 bours) 
When sodium chloride and calcium chloride are used together in the roasting process, the extraction yield of the three metals is higher than with the chlorinating agents alone. This condition is as a result of a lower melting point when the chlorinating agents are used. This situation increases the fluidity of the chloride melt while decreasing the viscosity of the liquid phase. In this case, the chloride mixture covers the surface of the boron waste and results in easy extraction of $\mathrm{Li}$, $\mathrm{Rb}$, and Cs (8).

The mixture (waste: $\mathrm{NaCl}: \mathrm{CaCl}_{2}$ ) was prepared by maintaining the mass ratio at 1:0.6:0.4 and roasted at $700{ }^{\circ} \mathrm{C}$ for 2 hours. Then the mixture was leached with deionized water for 1 hour at room temperature. The obtained results for $\mathrm{Li}, \mathrm{Rb}$, and Cs were $72.5 \%, 70.64 \%$, $73.69 \%$, respectively. It shows that the extraction yield of $\mathrm{Li}, \mathrm{Rb}$, and $\mathrm{Cs}$ is much higher when $\mathrm{NaCl}$ and $\mathrm{CaCl}_{2}$ are used together in the roasting process.

Figure 5 shows the XRD patterns of the roasted waste sample with and without chlorinating agents at $700{ }^{\circ} \mathrm{C}$. It can be seen that $\mathrm{Na}\left(\mathrm{Si}_{3} \mathrm{Al}\right) \mathrm{O}_{8}, \mathrm{KCl}, \mathrm{CaAl}_{2} \mathrm{Si}_{2} \mathrm{O}_{8}$ and $\mathrm{NaCl}$ are the products of chlorina-

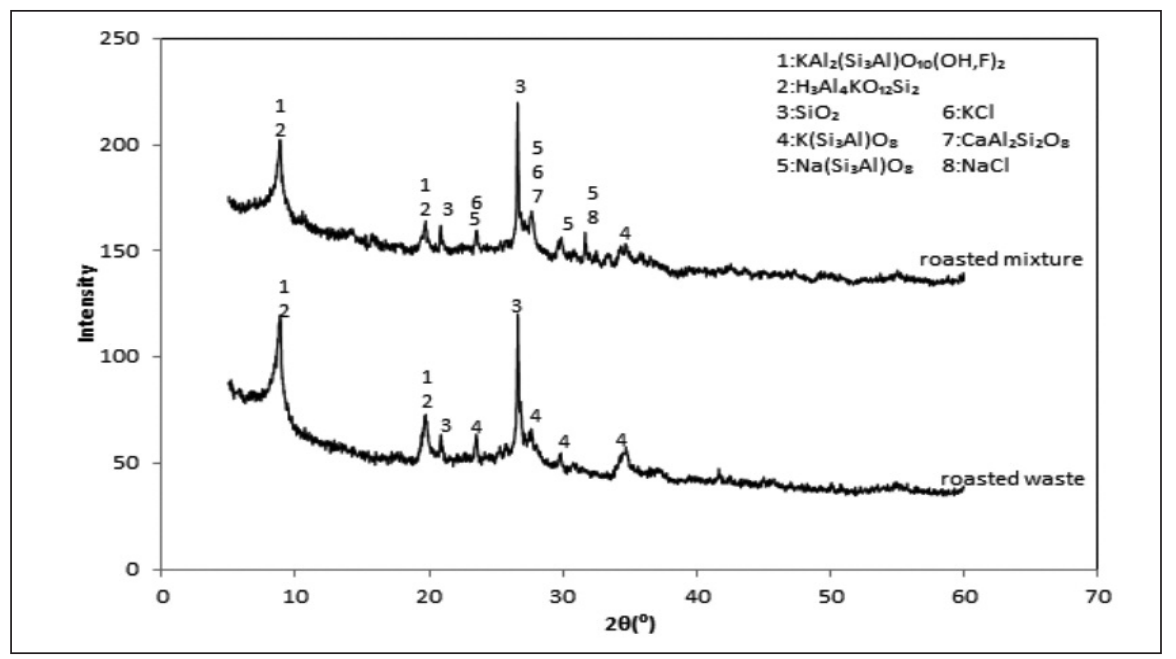

Fig. 5. XRD patterns of roasted waste sample with and without chlorinating agents. (Roasting temperature: $700{ }^{\circ} \mathrm{C}$, roasting time: 2 bours, mixture ratio ( $m$ (waste sample): $\left.\left.m(\mathrm{NaCl}): m\left(\mathrm{CaCl}_{2}\right)\right)=1: 0.6: 0.4\right)$.

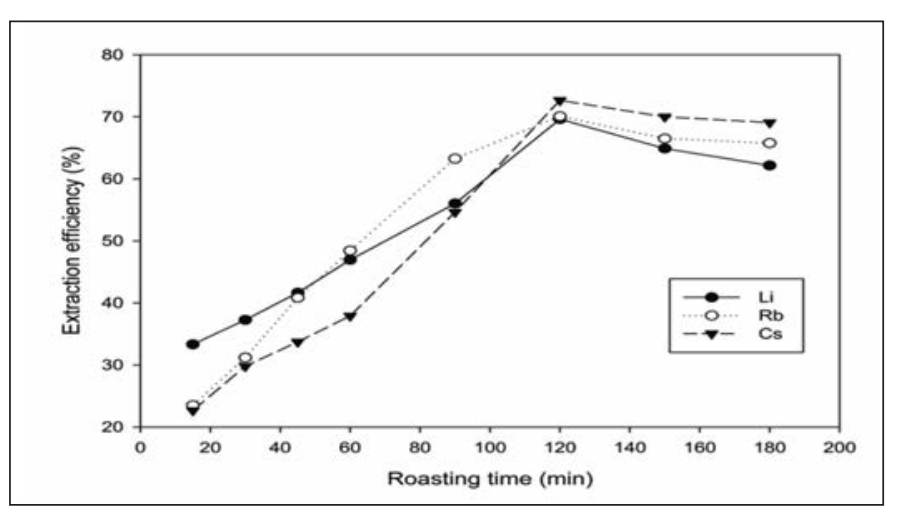

Fig. 6. Effect of chlorination roasting time on metal extraction (roasting temperature: $700{ }^{\circ} \mathrm{C}, \mathrm{m}$ (waste sample):

$\left.m(\mathrm{NaCl}): m\left(\mathrm{CaCl}_{2}\right)=1: 0.6: 0.4\right)$.

\section{Atomic Apectroscopy \\ 1 Vol. 39(4), July/August 2018

(a)

tion roasting. These products verify Eq. 1 and 3. When the waste sample was roasted alone, the $\mathrm{Li}, \mathrm{Rb}$, and $\mathrm{Cs}$ extraction efficiencies were $16.99 \%, 4.66 \%$, and 3,65\%, respectively. After addition of chlorination agents and roasting, extraction yields reached up to $72.5 \%, 70.64 \%$, $73.69 \%$.

\section{Effect of Roasting Time With Chlorination Process}

The mixtures prepared with the determined ratios roasted at $700^{\circ} \mathrm{C}$ for 15-180 minutes. Figure 6 shows that the maximum extraction efficiency is obtained at 120 minutes. Therefore, further experiments were carried out for 120 minutes.

\section{Effect of Leaching Time and Temperature}

The sample mixture roasted at $700{ }^{\circ} \mathrm{C}$ for 120 minutes at the mass ratio of $\mathrm{m}$ (boron waste) : $\mathrm{m}(\mathrm{NaCl})$ : $\mathrm{m}\left(\mathrm{CaCl}_{2}\right)=1: 0.6: 0.4$ was then subjected to water leaching. During the leaching tests, the solid-to-liquid ratio held steady at the ratio of $1: 2.5$ and the tests were carried out at different temperatures $(30,60$, $\left.90^{\circ} \mathrm{C}\right)$. The effect of leaching time and temperature on $\mathrm{Li}, \mathrm{Rb}$, and $\mathrm{Cs}$ extraction were investigated and are shown in Figures 7, 8, and 9 for each metal.

Figure 7 shows that the leaching time of 45 minutes at $90{ }^{\circ} \mathrm{C}$ for

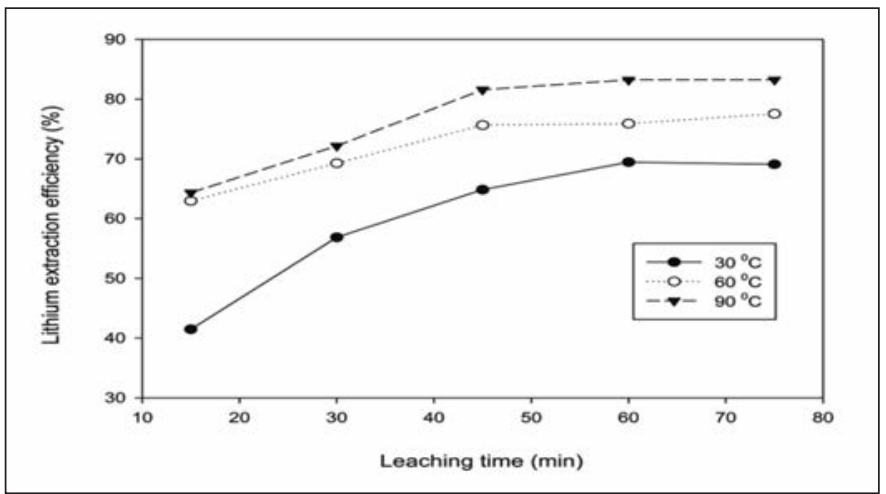

Fig. 7. Effect of leaching time and temperature on lithium extraction. 
lithium extraction is the most suitable condition. But Figures 8 and 9 show that the most reasonable temperature for $\mathrm{Rb}$ and $\mathrm{Cs}$ extraction is $60{ }^{\circ} \mathrm{C}$ and 45 minutes to reach equilibrium. In addition, extraction of the three metals was studied together from the same sample with the same method and showed that $60{ }^{\circ} \mathrm{C}$ for 45 minutes is the most economical condition.

\section{Effect of Solid-to-Liquid Ratio}

The solid-to-liquid (S/L) ratio was changed from 0.1 to 1.0 . The mass ratio of boron waste to $\mathrm{NaCl}$ to $\mathrm{CaCl}_{2}$ was kept constant at 1:0.6:0.4. The chlorination roasting temperature of $700{ }^{\circ} \mathrm{C}$ and chlorination roasting time of 120 minutes were the stable conditions and 45 minutes leaching time at $60{ }^{\circ} \mathrm{C}$ was also the steady situation for the leaching process. Figure 10 shows the effect of the $\mathrm{S} / \mathrm{L}$ ratio on the extraction of $\mathrm{Li}, \mathrm{Rb}$, and $\mathrm{Cs}$.

Figure 10 shows that the extraction yield seems to be stable up to the ratio of 0.4 for the three metals. After this point, the extraction efficiencies decrease slightly. At the ratio of 0.4 , the $\mathrm{Li}, \mathrm{Rb}$, and $\mathrm{Cs}$ extraction efficiencies were $75.01 \%$, $84.15 \%$, and $89.90 \%$ respectively. Thus, this ratio is considered to be most favorable and economical.

\section{CONCLUSION}

In this study, a chlorination roasting-water leaching process was used to optimize the extraction conditions of $\mathrm{Li}, \mathrm{Rb}$, and $\mathrm{Cs}$ from industrial boron waste. The conditions used were as follows: Chlorinating roasting temperature $700{ }^{\circ} \mathrm{C}$, mass ratio of boron waste to $\mathrm{NaCl}$ to $\mathrm{CaCl}_{2}$ 1:0.6:0.4, chlorinating

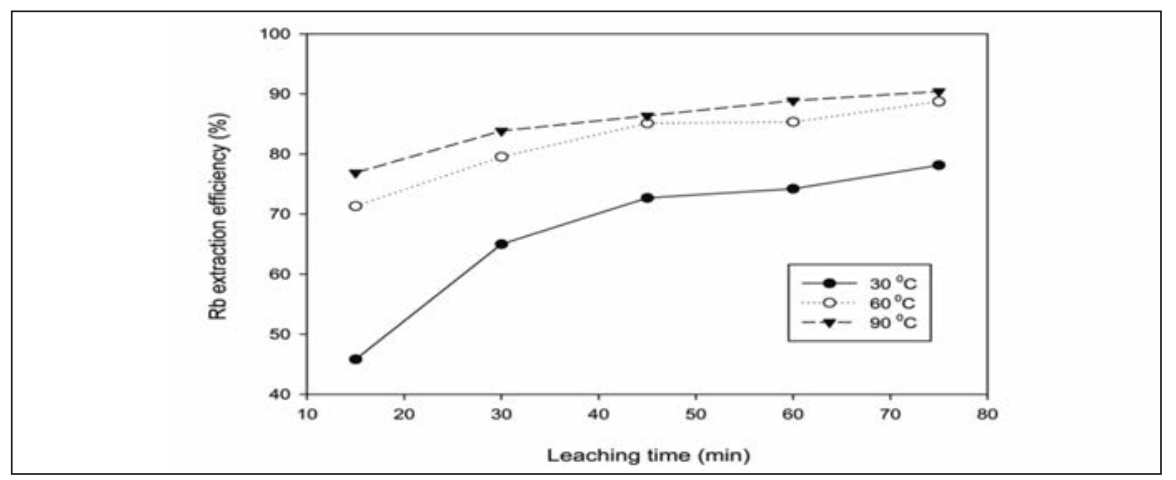

Fig. 8. Effect of leaching time and temperature on rubidium extraction.

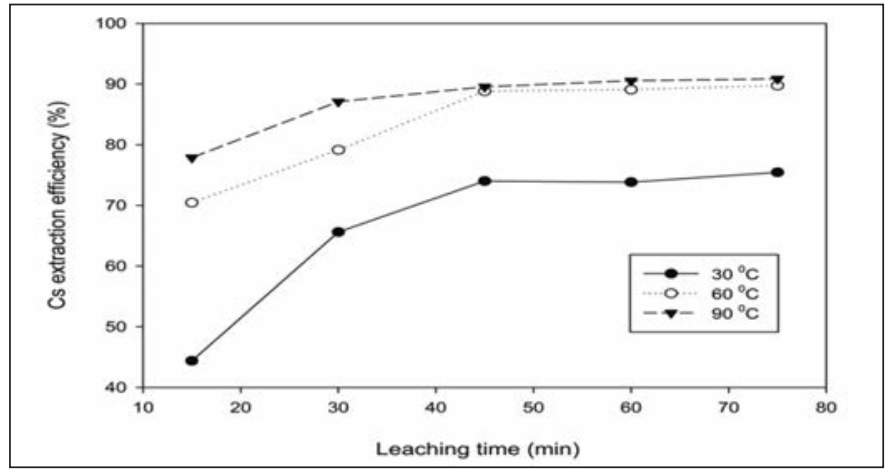

Fig. 9. Effect of leaching time and temperature on cesium extraction.

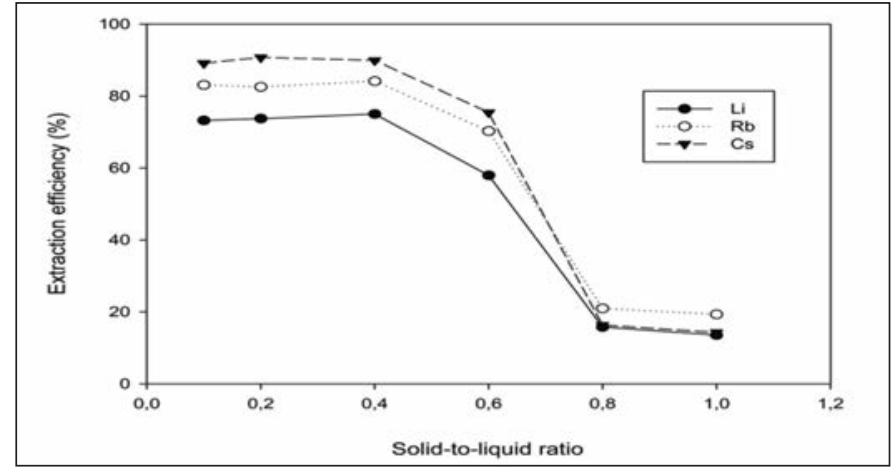

Fig. 10. Effect of solid-to-liquid ratio in leaching process. roasting time of 120 minutes, leaching temperature and time $60^{\circ} \mathrm{C}$ and 45 minutes, solid-to-liquid ratio of 0.4 . The extraction efficiencies of $\mathrm{Li}, \mathrm{Rb}$, and $\mathrm{Cs}$ reached peak values of $75.01 \%, 84.15 \%$, and $89.90 \%$, respectively. Thus this study shows that future researchers can use this method to recover these valuable metals from the leach liqours of waste samples and is also a precursor for recovery studies.

\section{ACKNOWLEDGMENT}

This work was supported by Dumlupinar University Scientific Research Projects Foundation, Turkey (Project no: 2013-37).

Received November 7, 2017.

\section{REFERENCES}

1. Z.E. Erkan, A. Akar, and M. Savaş, BAÜ Fen Bil. Enst. Dergisi 5.1, 161 (2003).

2. C. Helvacı, H. Mordoğan, M. Çolak, and İ. Gündoğan, Int. Geol. Rev. 46, 177 (2004).

3. F. Özmal and Y. Erdoğan, J. Env. Chem. Engineering 3(4) A, 2670 (2015).

4. B. Ertan and Y. Erdoğan, Powder Technol. 295, 254 (2016). 


\section{Atomic $_{\text {Spectroscopy }}^{\text {to }}$ \\ $\bigcirc$ Vol. 39(4), July/August 2018}

5. A. Kitajou, T. Suzuki, S. Nishihama, and K. Yoshizuka, Ars Separatoria Acta 2, 97 (2003).

6. Jaskula B.V., Mineral Commodity Summaries, U.S. Geological Survey (703), 648-4908, 100 (2016).

7. W.C. Buttermann and R.G. Reese, U.S. Geological Survey, Open File Report 03-045, 3 (2003).

8. Q. Yan, X. Li, Z. Wang, J. Wang, H. Guo, Q.Hu, W. Peng, and X. Wu, Trans. Nonferrous Met. Soc. China 22, 1753 (2012).

9. Q. Yan, X. Li, Z. Wang, X. Wu, H. Guo, Q. Hu, W. Peng, J. Wang, Hydrometallurgy 117-118, 116 (2012).

10. J. Jandová, P. Dvoŕák, J. Formanek, and H.N.Vu, Hydrometallurgy 119-120, 73 (2012).

11. H. Vu, J. Bernardi, J. Jandová, L. Vaculíková, and V. Goliáš, Int. J. Miner. Process. 123, 9 (2013).

12. M.R. Tavakoli Mohammadi, S.M. Javad Koleini, S. Javanshir, H. Abolghasemi, and M. Abdollahy, Hydrometallurgy 151, 25 (2015).

13. L. Zhou, T.Yuan, R. Li, Y. Zhong, and $\mathrm{X}$. Lei, Hydrometallurgy 158, 61 (2015).

14. C.A. Tuck, Mineral Commodity Summaries, U.S. Geological Survey 703, 648-4912, 138 (2016).

15. W.C. Butterman, W.E. Brooks, R.G. Reese, U.S. Geological Survey, Open File Report 20041432, 1 (2005).

16. C.A. Tuck, Mineral Commodity Summaries, U.S. Geological Survey 703, 648-4912, 46 (2016).

17. P. Meshram, B.D. Pandey and T.R. Mankhand, Hydrometallurgy 150, 192 (2014). 